\title{
Effect of red tide dinoflagellate diet and cannibalism on the bioluminescence of the heterotrophic dinoflagellates Protoperidinium spp.
}

\author{
Michael I. Latz ${ }^{1, *}$, Hae Jin Jeong ${ }^{2, * *}$ \\ ${ }^{1}$ Marine Biology Research Division 0202, Scripps Institution of Oceanography, University of California San Diego, La Jolla, \\ California 92093-0202, USA \\ ${ }^{2}$ Marine Life Research Group 0218, Scripps Institution of Oceanography, University of California San Diego, La Jolla, \\ California 92093-0218, USA
}

\begin{abstract}
The effects of diet and cannibalism were assessed from changes in the bioluminescence potential of 2 specle's of the heterotrophic dinoflagellate Protoperidinium fed 4 species of red tide dinoflagellate prey and also maintained without added prey. The use of bioluminescence as a sensitive indicator of nutritional status and feeding was explored. The bioluminescence of Protoperidinium cf. divergens and $P$. crassipes was significantly affected by dinoflagellate diet. Total mechanically stimulable luminescence (TMSL) of $P$. cf. divergens fed different dinoflagellate diets was significantly correlated with feeding frequency (the percent of feeding $P$. cf. divergens cells) rather than with population growth rate. $P$. of. divergens displayed high levels of TMSL and feeding frequency on a diet of Scrippsiella trochoidea which did not support population growth. Diet did not affect the total number of flashes produced per cell; therefore, changes in TMSL with dinoflagellate diet were related to the amount of chemical substrate available for luminescence, rather than changes in the excitation/transduction process. Individually isolated cells remained viable for only 3 to $5 \mathrm{~d}$ without food and exhibited reduced bioluminescence. However, cells maintained in groups survived at least $16 \mathrm{~d}$ without added prey and maintained levels of bioluminescence similar to those during favorable prey conditions. Canmibalism observed during this time may have enabled cells of $P$. cf. divergens to feed and therefore produce high levels of bioluminescence in the absence of added prey. Changes in swimming speed were less than changes in bioluminescence. The results of the present study suggest that energy utilization may be prioritized in the following order: swimming (for grazing) > bioluminescence (for reducing predation) > reproduction (for increasing the population).
\end{abstract}

KEY WORDS: Bioluminescence Cannibalism Dinoflagellate Energetics-Microzooplankton Plankton Predation Red tıde

\section{INTRODUCTION}

The high abundance and diverse ecological roles of heterotrophic dinoflagellates (Beers et al. 1982, Lessard 1984) attest to their importance in the marine environment. In particular, the ubiquitous heterotrophic dinoflagellate genus Protoperidinium can be an important component in plankton dynamics for the

\footnotetext{
-E-mail: mlatz@ucsd.edu

- Present address: Department of Oceanography, College of Natural Sciences, Kunsan National University, Kunsan 573 701 , South Kored
}

following reasons. First, it is among the most abundant of the $>20 \mu \mathrm{m}$ heterotrophic dinoflagellates found in coastal and oceanic waters (Lessard 1984, Hallegraeff \& Reid 1986, Lessard \& Rivkin 1986, Jacobson 1987), particularly during some dinoflagellate red tides (Jeong 1995) or diatom blooms (Jacobson 1987). Second, it is not only an important prey for copepods (Gifford \& Dagg 1991, Jeong 1994a), but also a predator of copepod eggs and early naupliar stages (Jeang 1994b). Third, the diet of Protoperidinium spp, includes a broad range of prey species (Jacobson \& Anderson 1986, Buskey et al. 1994, Jeong 1994 b, Jeong \& Latz 1994). Fourth, in some regions 
they have recently been recognized as major sources of bioluminescence in the mixed layer (Lapota et al 1989, 1992a, b, Swift et al. 1995).

Bioluminescence in dinoflagellates is believed to serve an anti-predation function by reducing predation pressure (Esaias \& Curl 1972, White 1979) and by acting as a 'burglar alarm' which increases the vulnerability of the grazer to secondary predation (Mensinger \& Case 1992, Abrahams \& Townsend 1993), Therefore, bioluminescence may be an important factor in predator-prey interactions and the structuring of biological communities.

The bioluminescence capacity of heterotrophic dinoflagellates appears to be dependent on short-term nutritional status, i.e. the total energy resources available for all physiological processes. Nutritional status and bioluminescence are affected by prey concentration (Buskey et al. 1992, 1994), photosynthesis by symbiotic algae if present (Sweeney 1971), and starvation time (Buskey et al. 1992, 1994). Because a luminescent predator usually experiences a variety of prey sources and conditions, bioluminescence must be measured for different nutritional conditions, as well as for a unialgal diet, in order to fully understand the relationships between bioluminescence and prey availability.

In the case of a luminescent predator such as Protoperidinium spp., the energy obtained from grazing is needed not only for metabolism, swimming, and reproduction, but also for light production. Energy is required for synthesis of the luminescent chemistry, its transport through the cytoplasm, and packaging into membrane-bound vesicles called scintillons which are associated with the vacuolar membrane (Nicolas et al. 1991). The energy requirement for producing bioluminescence is unknown, as is the priority of the luminescent system in terms of energy utilization.

The population growth of a predator can be indicative of its nutritional status when feeding on different prey species and concentrations (e.g. Buskey et al. 1994, Jeong \& Latz 1994). However, the energy available for bioluminescence and swimming may be similar even when different population growth rates indicate that different amounts of energy are available for reproduction. For example, Protoperidinium cf. divergens has similar maximum feeding frequencies for both the larger prey Gonyaulax polyedra and the smaller prey Scrippsiella trochoidea, even though its population growth rate for a $S$. trochoidea diet is zero and that for a G. polyedra diet is high (Jeong \& Latz 1994). More information is needed on whether a particular diet provides sufficient energy resources for maintenance and bioluminescence, even when insufficient for reproduction. The nutritional status of a predator may be strongly related to survivorship and thus population dynamics. In the present study, the use of bioluminescence of a predator as an indicator for nutritional status and feeding is explored and compared with other indicators such as population growth rate and swimming speed.

Cannibalism in the genus Protoperidinium occurs mainly when its abundance is high and prey abundance is low (Jeong \& Latz 1994), a situation which is expected to occur just after some dinoflagellate red tides. Cannibalism may affect the bioluminescence of Protoperidinium under unfavorable prey conditions; changes in bioluminescence under these conditions may possibly provide an indirect measure of the rate of cannibalism. Cannibalism by Noctiluca scintillans is suspected to explain the increased levels of bioluminescence of cells held in groups compared to that of individually maintained cells (Buskey et al. 1992).

The objective of the present study was to test the following hypotheses regarding the relationship between bioluminescence and nutritional status:

$\mathrm{H}_{0} 1$ : The bioluminescence of Protoperidinium cf. divergens is similar for all unialgal dinoflagellate diets.

$\mathrm{H}_{0} 2$ : If there are differences in population growth rates for Protoperidinium cf. divergens feeding on various unialgal red tide dinoflagellate diets, then bioluminescence will be different.

$\mathrm{H}_{0} 3$ : Prey concentration does not significantly affect the bioluminescence of Protoperidinium cf. divergens.

$\mathrm{H}_{0} 4$ : The bioluminescence of Protoperidinium of. divergens without added prey is not significantly different from that of $P$. cf. divergens feeding on optimal prey.

\section{MATERIALS AND METHODS}

Culture of experimental organisms. Cultures of Protoperidinium cf. divergens and $P$. crassipes, which are abundant during some red tides (Jeong 1995), were established from cells collected from the Scripps Pier (La Jolla, CA, USA) during October, 1992. Details of the culturing of these species are described by Jeong \& Latz (1994). Cultures were maintained on a unialgal diet of Gonyaulax polyedra in polycarbonate (PC) bottles. Every 3 to $4 \mathrm{~d}$ the $P$. cf. divergens culture was first sieved through $64 \mu \mathrm{m}$ Nitex mesh to remove debris, then re-sieved so that cells were retained on $53 \mu \mathrm{m}$ mesh. $P$. crassipes cells were first sieved through $100 \mu \mathrm{m}$ mesh to remove debris, then re-sieved through $64 \mathrm{fm}$ mesh to retain cells. The sieving procedure maintained a homogeneous population size distribution and minimized cell size effects on bioluminescence emission.

Prey cultures of the autotrophic or mixotrophic dinoflagellates Gonyaulax polyedra, Gymnodinium sanguineum, Heterocapsa triquetra, Prorocentrum cf. 
balticum, and Scrippsiella trochoidea, were grown in $\mathrm{f} / 4$ enriched seawater media (Guillard \& Ryther 1962), minus silicate, at room temperature $\left(20\right.$ to $\left.23^{\circ} \mathrm{C}\right)$ under continuous cool white fluorescent illumination of $5 \times 10^{15}$ quanta $\mathrm{cm}^{-2} \mathrm{~s}^{-1}$. Cultures in exponential growth phase were used for feeding experiments. Cell concentrations were determined from total cell counts of $1 \mathrm{ml}$ aliquots.

Experimental design. The initial concentrations of Protoperidinium cf. divergens and its prey are given in Table 1. For all experiments, cells between 53 and $64 \mu \mathrm{m}$ in diameter were chosen in order to minimize effects due to cell size. Expt 1 was designed to test $\mathrm{H}_{0} 1$ and $\mathrm{H}_{0} 2$ (effect of prey species). The initial concentrations of algal prey, based on the results of Jeong \& Latz (1994), were obtained by volume dilution, and were chosen for the following reasons: a Gonyaulax polyedra concentration of 2000 cells mi 'results in a maximum growth rate of $P$. cf. divergens; a Gymnodinium sanguineum concentration of 700 cells ml-1 ${ }^{-1}$ results in a positive growth rate, while that of 2000 cells ml-1 results in a negative growth rate. A Scrippsiella trochoidea diet results in zero growth for cell concentrations between 1000 and 6000 cells ml-1, although feeding still ocrur; therefore, an intermediate concentration of $5000 \mathrm{cell}_{\mathrm{s} \mathrm{m}} \mathrm{ml}^{-1}$ was used. There is neither feeding by $P$. cf. divergens on Prorocentrum cf. balticum nor a positive population growth rate for all prey concentrations tested (Jeong \& Latz 1994); therefore, an intermediate prey concentration of 5000 cells $\mathrm{ml}^{-1}$ was used.

Dense cultures of Prorocentrum cf. divergens and $P$. crassipes were maintained on particular prey for $1 \mathrm{wk}$,

Table 1. Initial concentrations of Protoperidinium cf. divergens and prey and incubation times used in each experiment. See text for experimental details

\begin{tabular}{|c|c|c|c|}
\hline $\begin{array}{l}\text { Expt } \\
\quad \text { Prey species }\end{array}$ & $\begin{array}{l}\text { Prey conc. G } \\
\text { (cell } \mathrm{ml}^{-1} \text { ) }\end{array}$ & $\begin{array}{c}\text { Grazer conc } \\
\left(\text { cell } \mathrm{ml}^{-1}\right)\end{array}$ & $\begin{array}{l}\text { Incub. time } \\
\text { (d) }\end{array}$ \\
\hline \multicolumn{4}{|l|}{ 1. Effect of unialgal diet } \\
\hline Gonyaulax polyedra & 2000 & 1 & 4 \\
\hline Gymnodinım sanguineum & 700.2000 & 1 & 4 \\
\hline Scrippsiella trochoidea & 5000 & 1 & 4 \\
\hline Heterocapsa triquetra & 5000 & 1 & 4 \\
\hline Prorocentrum cf. balticum & 5000 & 1 & 4 \\
\hline \multicolumn{4}{|l|}{ 2. Effect of prey concentration } \\
\hline G. polyedra & $\begin{array}{c}70,300,700 \\
1400,2000,3000\end{array}$ & 0 & 4 \\
\hline \multicolumn{4}{|l|}{ 3. Single cell starvation } \\
\hline None & & 1 cell & $1,2,3$ \\
\hline \multicolumn{4}{|c|}{ 4. Group maintenance without added prey } \\
\hline None & & 40 & $\begin{array}{l}1,3,5,7 \\
9,12,16\end{array}$ \\
\hline \multicolumn{4}{|l|}{ 5. Long-term culturng } \\
\hline G. polyedra & 2000 & 1 & 130 \\
\hline G. sanguineum & 750 & 1 & 53 \\
\hline
\end{tabular}

then sieved though 53 and $64 \mu \mathrm{m}$ mesh, respectively, Retained cells were first transferred to multiwell chambers, then initial concentrations of 1 Protoperidinium $\mathrm{ml}^{-1}$ were obtained by individually transferring actively swimming cells by a Pasteur pipette into $32 \mathrm{ml}$ polycarbonate (PC) bottles filled with freshly filtered seawater, 1 to $2 \mathrm{ml} \mathrm{f/4}$ medium, and target prey. For the unfed control condition no prey were added. Botthes were rotated at $0.9 \mathrm{rpm}$ and maintained on a $12 \mathrm{~h}$ light:12 h dark (LD) cycle for a $4 \mathrm{~d}$ incubation period according to the methods of Jeong \& Latz (1994).

Expt 2 was designed to test $\mathrm{H}_{0} 3$ (effect of prey concentration). Based on feeding studies with 5 dinoflagellate prey species, Gonyaulax polyedra was chosen for this experiment because it is the optimal dinoflagellate prey for Protoperidinium cf. divergens, with positive population growth for prey concentrations $\geq 100$ cells $\mathrm{ml}^{-1}$ (Jeong \& Latz 1994). The initial prey concentrations of 70 to 2500 G. polyedra cells mi were obtained by volume dilution and the grazer concentration by individually transferring cells as described above. Bottles were rotated as for Expt 1. Because 53 to $64 \mu \mathrm{m}$ diameter cells were selected for testing, $P$. cf. divergens cell size was similar for each prey concentration treatment (ANOVA, $\mathrm{p}>0.05$ ).

Expts 3 and 4 were designed to test $\mathrm{H}_{0} 4$ (effect of cannibalism). Two methods were used for single-cell starvation studies (Expt 3). All cells of Protoperidinium cf. divergens were isolated from cultures maintained on a Gonyaulax polyedra diet as described above. Single cells were transferred to individual $10 \mathrm{ml}$ PC bottles which were filled with filtered sea water, tightly capped, and rotated (method 1). Cells were tested for bioluminescence after 0,3 , and $5 \mathrm{~d}$. Other single cells were placed in $7 \mathrm{ml}$ glass scintillation vials partially filled with $4 \mathrm{ml}$ of filtered sea water, loosely capped, and not rotated (method 2). Cells were tested for bioluminescence after 1, 2, and $3 \mathrm{~d}$. For both methods cells were maintained on a $12 \mathrm{~h}$ light:12 h dark cycle at room temperature; each cell was tested once.

For group maintained cells without added prey (Expt 4), cells of Protoperidinium cf. divergens maintained on a Gonyaulax polyedra diet as described above were completely separated from prey cells and debris by sieving through 53 and $64 \mu \mathrm{m}$ Nitex mesh, respectively. They were then resuspended in filtered seawater in $270 \mathrm{ml}$ PC bottles. Bottles were rotated as for Expt 1. Cells 53 to 64 $\mu \mathrm{m}$ in diameter were tested for bioluminescence after $0,1,3,5,7,9,12$, and $16 \mathrm{~d}$. 
Cell size in aliquots maintained under the same conditions was measured using an Elzone model 280PC particle counter with a calibrated $120 \mu \mathrm{m}$ orifice (Jeong \& Latz 1994).

The long-term effect of diet (Expt 5) was investigated to determine if there is a dietary requirement for bioluminescence. Cells of Protoperidinium cf. divergens were incubated in $43 \mathrm{ml} \mathrm{PC}$ bottles on a diet of luminescent Gonyaulax polyedra or a diet of nonluminescent Gymnodinium sanguineum. At $4 \mathrm{~d}$ intervals, cells were sieved and new prey culture added (Jeong \& Latz 1994). The bioluminescence of $P$. cf. divergens cells at Day 0 and Day 50 was measured.

The bioluminescence of freshly collected Protoperidinium cf. divergens was measured from cells collected in the afternoon by plankton net tows from the Scripps Pier as described above, then individually isolated by Pasteur micropipette. Cells were placed in the dark at local sunset (17:00 h) for bioluminescence medsurements.

The bioluminescence of Protoperidinium crassipes was tested for a Gonyaulax polyedra diet at an initial prey concentration of 2000 cells $\mathrm{ml}^{-1}$, where high population growth occurs (Jeong \& Latz 1994)

Bioluminescence measurements. Cells were prepared for testing toward the end of the light phase, when bioluminescence is minimally excitable (Biggley et al. 1969, Lapota et al. 1992a). Cells were rinsed by micropipette transfer into filtered seawater, and individually placed into $7 \mathrm{ml}$ glass scintillation vials containing $2 \mathrm{ml}$ filtered seawater. Unless otherwise stated, 20 cells were tested at a room temperature of $20 \pm 1^{\circ} \mathrm{C}$.

Bioluminescence was measured in a calibrated detection apparatus consisting of a $15 \mathrm{~cm}$ diameter integrating sphere collector coupled to a photon-counting photomultiplier (Latz \& Lee 1995). Testing was performed during Hours 2 to 4 of the dark phase when high levels of stimulated dinoflagellate biolumines- cence occur (Biggley et al. 1969, Lapota et al. 1992a). Single flashes were elicited during continuous stirring of the contents of the vial. Stirring was maintained for $160 \mathrm{~s}$, the length of a data acquisition record, and was repeated until total depletion of luminescence to determine total mechanically stimulable luminescence (TMSL), a measure of bioluminescence capacity.

Analysis. Bioluminescence capacity as a function of dinoflagellate diet was determined based on several parameters analyzed as described in Latz \& Lee (1995). These parameters provide information on how the packaging and activation of the luminescent system may be affected by nutritional status. Total light emission per cell was expressed as TMSL, which is a function of the total number of flashes produced and the quantum emission per flash. Flash quantum emission is proportional to flash maximum flux (intensity), the intensity of the brightest flash from each cell. The total duration of individual flashes is the sum of rise time (period from initial to maximum flux) and flash decay (period from maximum flux to $3 \%$ of maximum) (Latz \& Lee 1995). The instantaneous decay rate is the inverse of the e-fold time (duration from maximum flux to $e^{-1}$ of maximum). Unless otherwise stated, values represent mean \pm 1 standard error (SE) of the mean, and statistical differences were tested at the $0.05 \mathrm{sig}$ nificance level with 1-way Analysis of Variance (ANOVA) using Statview software (Abacus Concepts, Inc.). Multiple comparisons were based on the Scheffe test (Winer 1971).

Surface area $(S A)$ of individual cells was calculated according to the formula $S A=4 \pi(D / 2)^{2}$, where $D$ is the equivalent spherical diameter based on the formula $D=(L \times W \times T)^{1 / 3}($ Kamykowski et al. 1992), where $L, W$, and $T$ are mean cell length, width, and thickness, respectively, measured using an ocular micrometer. Cell volume $(V)$ was calculated as $V=4 / 3 \pi(D / 2)^{3}$. Values are expressed as the mean $\pm S E$.

Table 2. Growth rate, maximum feeding frequency and total mechanically stimulable luminescence (TMSL) of Protoperidinium cf. divergens resulting from different heterotrophic dinoflagellate diets in Expt 1. Diets are listed in order of those which resulted in most bioluminescence. ESD: equivalent spherical diameter of cells measured with an electronic cell counter; maximum feeding frequency: instantaneous measure of the percent of the population feeding (based on the presence of a pallium). Growth and feeding data from Jeong \& Latz (1994). "TMSL significantly different from that of cells maintained without added prey (Fisher's PLSD, $p<0.05)$. - no data

\begin{tabular}{|c|c|c|c|c|}
\hline Prey species & $\begin{array}{l}\text { Prey size } \\
(\mathrm{ESD}, \mu \mathrm{m})\end{array}$ & $\begin{array}{c}\text { Growth rate } \\
\qquad\left(\mathrm{d}^{-1}\right)\end{array}$ & $\begin{array}{l}\text { Maximum feeding } \\
\text { frequency }(\%)\end{array}$ & $\begin{array}{c}\text { TMSL } \\
\text { (quanta cell }{ }^{-1} \text { ) }\end{array}$ \\
\hline Gonyaulax polyedra & 37 & 0.5 & 27 & $6.2 \times 10^{8}$ \\
\hline Scrippsiella trochoidea & 19 & 0 & 25 & $6.0 \times 10^{8}$ \\
\hline Gymnodinium sanguineum 700 cells $\mathrm{ml}{ }^{\prime}$ & 32 & 0.2 & 20 & $5.9 \times 10^{9}$ \\
\hline G. sanguineum 2000 cells $\mathrm{mI}^{-1}$ & 32 & -0.2 & 0 & $2.9 \times 10^{8}$ \\
\hline Heterocapsa triquetra & 17 & 0 & - & $2.2 \times 10^{8}$ \\
\hline Prorocentrum cf balticum & 11 & 0 & 0 & $1.3 \times 10^{8}$ \\
\hline No prey added & - & - & - & $1.9 \times 10^{8}$ \\
\hline
\end{tabular}


Swimming speed studies. Swimming speeds were measured for Protoperidinium cf. divergens under conditions of no added prey. Measurements were performed at $19 \pm 0.5^{\circ} \mathrm{C}$ using a video microscope setup (Jeong 1994a). Speeds were measured, during single frame playback, from linear displacements of actively swimming cells

\section{RESULTS}

\section{Test of $\mathrm{H}_{0} 1$ and $\mathrm{H}_{0} 2$ (effect of prey species)}

Expt 1 tested the effect of 5 different unialgal red tide dinoflagellate diets on the bioluminescence of Protoperidinium cf. divergens (Table 2). Because TMSL was significantly different between diets (ANOVA, $p<$ $0.001), \mathrm{H}_{0} 1$ can be rejected. However, the total number of flashes produced by each $P$. cf. divergens cell was similar (ANOVA, $\mathrm{p}>0.05$ ), and averaged $1.5 \pm 0.9$ flashes cell ${ }^{-1}(n=113)$ (Fig. 1). Even though all single flash variables exhibited statistical differences between prey conditions (ANOVA, $p<0.05$ ), there were few significant differences based on multiple comparisons (Table 3). Overall the greatest difference was in maximum flux (intensity), with few differences in flash kinetics, indicating that the activation of light emission was not affected by nutritional status.

A Gonyaulax polyedra diet yielded maximum bioluminescence, with a mean TMSL of $6.2 \times 10^{8}$ quanta cell ${ }^{-1}$ based on an average of 9.7 flashes cell ${ }^{-1}$, and a maximum flux (i.e. intensity of the brightest flash) of $9.6 \times 10^{8}$ quanta $\mathrm{s}^{-1} \mathrm{cell}^{-1}$.

For a Gymnodinium sanguineum diet at a prey concentration of 700 cells $\mathrm{ml}^{-1}$, considered optimum for Protoperidinium cf. divergens population growth (Jeong \& Latz 1994), the TMSL, flash flux, and number of flashes cell ${ }^{-1}$ of $P$. cf. divergens were not significantly different from those for a Gonyaulax polyedra $\operatorname{diet}(A N O V A, p>0.05$ ). However, at a concentration of $2000 \mathrm{G}$. sanguineum $\mathrm{ml}^{-1}$, where negative growth of $P$. cf. divergens occurs (Jeong \& Latz 1994), its bioluminescence was significantly reduced (ANOVA, p < 0.05).

When offered dinoflagellates not known to be grazed by Protoperidinium cf. divergens, including Heterocapsa triquetra and Prorocentrum cf. balticum (Jeong \& Latz 1994), P. cf. divergens exhibited bioluminescence not significantly different from unfed controls (Fig. 1; Table 2; ANOVA, p > 0.05).

Protoperidinium of divergens fed a Scrippsiella trochoidea diet had similar TMSL, maximum flux, and total flashes to those of cells maintained on Gonyaulax polyedra (Fisher's PLSD, $\mathrm{p}>0.1$ ), even though a $S$. trochoidea diet is not sufficient to support population
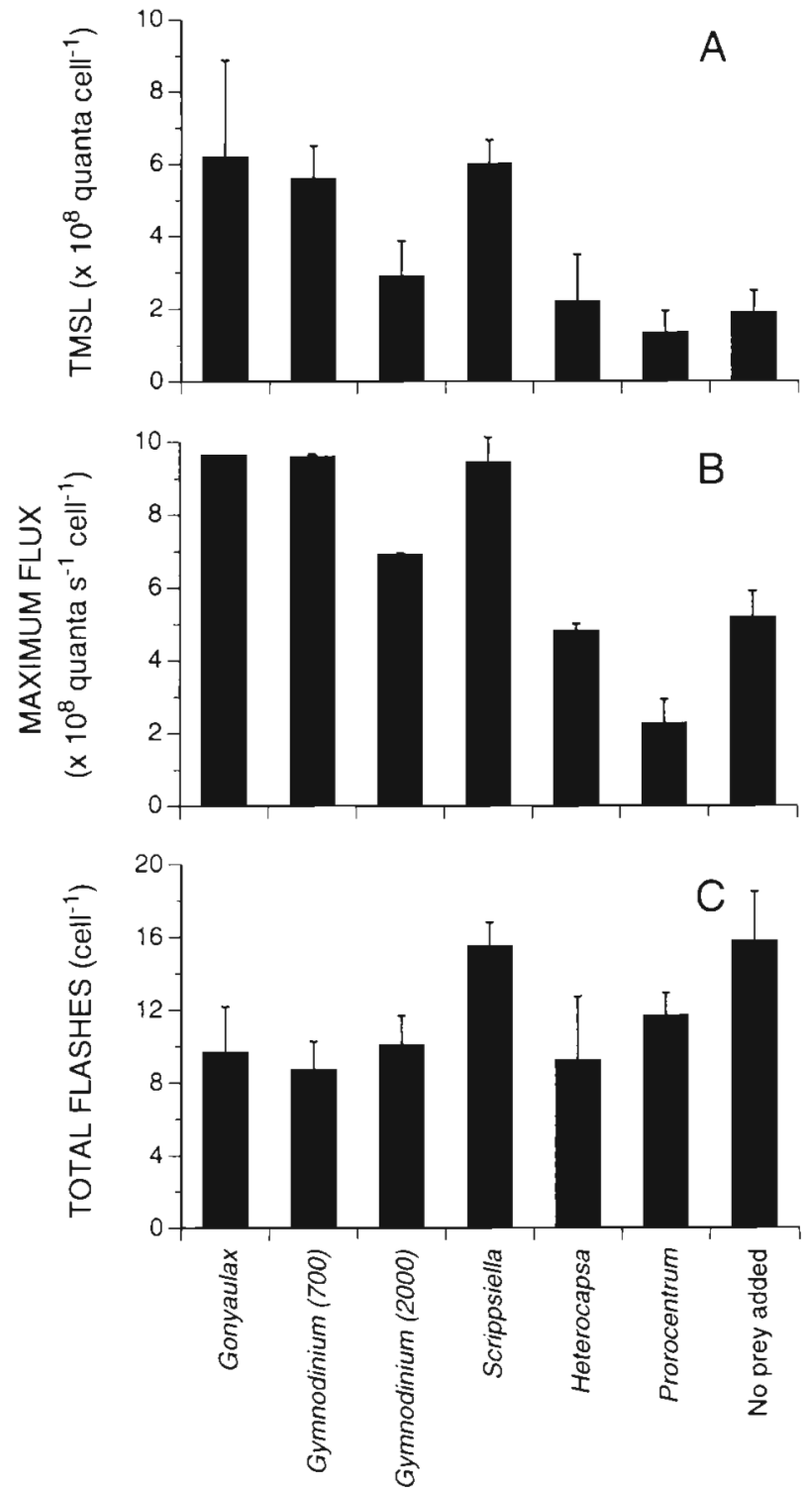

Fig. 1. Bioluminescence of Protoperidinium cf. divergens after $4 \mathrm{~d}$ incubation as a function of different unialgal autotrophic dinoflagellate diets in Expt 1. (A) Total mechanically stimulable bioluminescence (TMSL) as a function of dietary condition. (B) Maximum flux (intensity of the brightest flash) produced by each cell. (C) Total number of flashes produced by each cell. Values represent means \pm SE. See Table 1, Expt 1 for details

growth (Jeong \& Latz 1994). Therefore, $\mathrm{H}_{0} 2$ can be rejected.

\section{Test of $\mathrm{H}_{0} 3$ (effect of prey concentration)}

With increasing Gonyaulax polyedra concentration, TMSL of Protoperidinium cf. divergens increased up to 


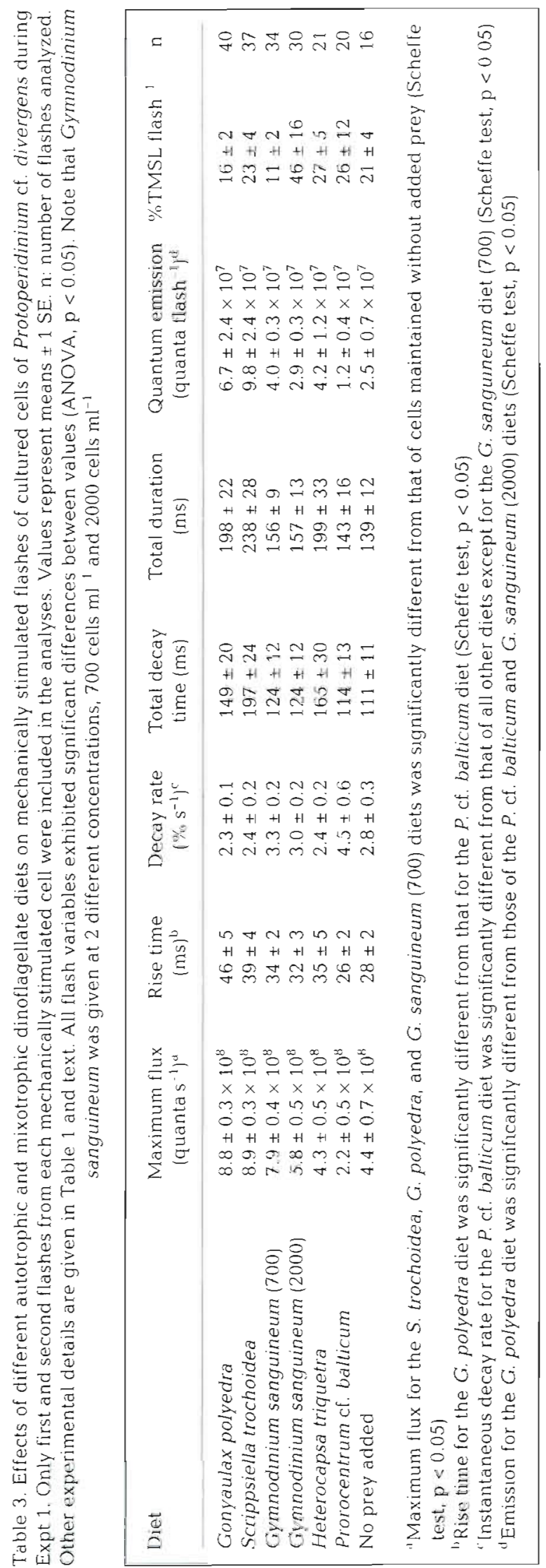

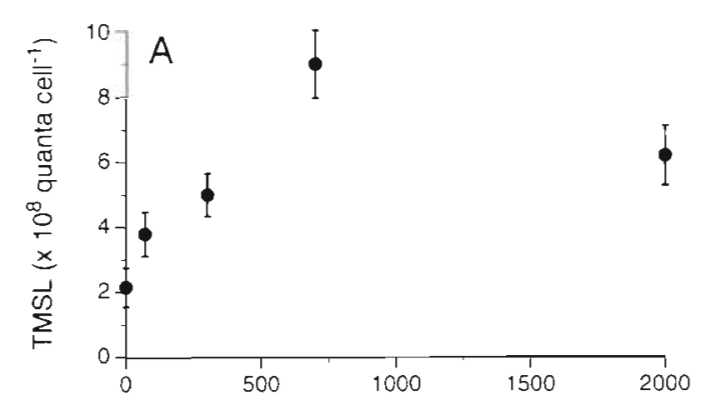
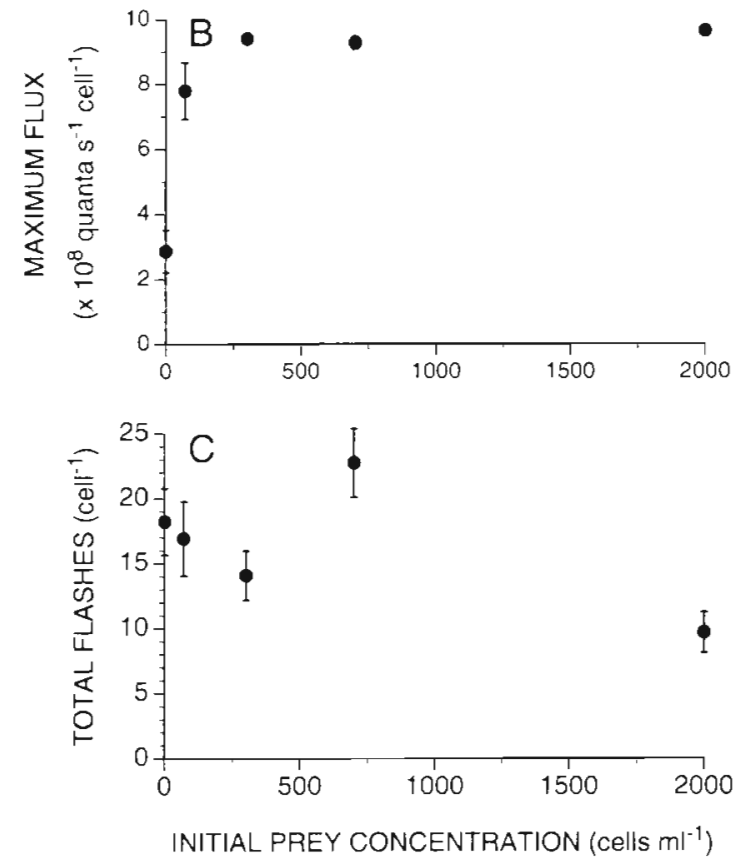

Fig. 2. Effect of Gonyaulax polyedra prey concentration on the bioluminescence of Protoperidium cf. divergens (see Table 1, Expt 2). Prey concentration was determined prior to incubation

a maximum of $9.1 \times 10^{8}$ quanta cell ${ }^{-1}$ at $700 \mathrm{G}$. polyedra $\mathrm{ml}^{-1}$, then decreased at higher prey concentrations (Fig. 2A). Maximum flux of each cell increased from $2.9 \times 10^{8}$ quanta s$^{-1}$ for the unfed control to $9.4 \times 10^{8}$ quanta $\mathrm{s}^{-1}$ at $300 \mathrm{G}$. polyedra $\mathrm{ml}^{-1}$; higher prey concentrations did not further increase maximum flux (Fig. 2B). There was no significant difference in the total number of flashes produced per cell as a function of prey concentration (ANOVA, p > 0.05) (Fig. 2C).

Because the bioluminescence of $P$. cf. divergens feeding on Gonyaulax polyedra was significantly different at different prey concentrations, $\mathrm{H}_{0} 3$ can be rejected.

\section{Test of $\mathrm{H}_{0} 4$ (effect of cannibalism)}

TMSL of cells maintained in groups without added prey initially decreased from a value of $4.1 \times 10^{8}$ 
quanta cell ${ }^{-1}$ on Day 0 to $8.5 \times 10^{7}$ quanta cell ${ }^{-1}$ after $3 \mathrm{~d}$, a value similar to that of single cells without added prey; however, TMSL of the cells maintained in groups increased to $4.6 \times 10^{8}$ quanta cell ${ }^{-1}$ after 16 d. The Day 16 TMSL was not significantly different from that measured on Day 0 for cultures well fed on a diet of Gonyaulax polyedra (initial condition) (ANOVA, p > 0.05; Fig. 3). Therefore, $\mathrm{H}_{0} 4$ cannot be rejected.

The maximum flux from each cell also decreased after $3 \mathrm{~d}$ without added prey for both group maintained and single isolated cells from an initial value of $9.2 \times$ $10^{8}$ quanta $\mathrm{s}^{-1}$ to $2.3 \times 10^{8}$ quanta $\mathrm{s}^{-1}$. However, for group maintained cells the maximum quantum flux cell $^{-1}$ subsequently increased to a maximum of $7.2 \times$ $10^{8}$ quanta $\mathrm{s}^{-1}$ after $16 \mathrm{~d}$. There was no significant temporal difference in the total number of flashes (ANOVA, $\mathrm{p}>0.05$ ), which averaged 10 flashes cell ${ }^{-1}$.

Cannibalism, observed in Protoperidinium cf. divergens populations maintained without added prey, was based on the presence of a $P$. cf. divergens cell within the pallium of a feeding cell. Cannibalism is believed to be responsible for the maintenance of high levels of bioluminescence.

For single isolated cells, in addition to the decrease in TMSL with starvation, the proportion of luminescing cells also decreased. After $1 \mathrm{~d}$ of starvation, 16 of 16 cells were luminescent, and after $2 \mathrm{~d}$ of starvation, 14 of 20 cells $(70 \%)$ were luminescent (method 2 ). For method 1, with 15 cells originally incubated for each test, after $3 \mathrm{~d}$ of starvation, 8 of 10 cells were luminescent $(80 \%$ response, $67 \%$ survival), while after $5 \mathrm{~d}$ of starvation only 1 of 6 cells produced flashes $(17 \%$ response, $40 \%$ survival) (method 1 ). Therefore starvation decreased bioluminescence and increased mortality of individually maintained cells.

\section{Effect of long-term laboratory culturing}

There was minimal effect of long-term culturing of Protoperidinium of. divergens on a unialgal diet of Gonyaulax polyedra. Over $4.5 \mathrm{mo}$ (from 4 Jan to 21 May 1993) there was no significant change in TMSL of $5.2 \times 10^{8}$ quanta cell ${ }^{-1}$ and total flash number of 10 flashes cell ${ }^{-1}$ (ANOVA, p > 0.05), and only a slight decrease in maximum flux per cell from $9.7 \times 10^{8}$ to $9.2 \times 10^{8}$ quanta s $^{-1}$ (ANOVA, $\mathrm{p}<0.05$ )

Because of the sieving process used as part of the culturing methods, cultured Protoperidinium cf. divergens cells were smaller in size than freshly collected (unsieved) cells (ANOVA, $\mathrm{p}<0.01$ ); cultured and collected cells had volumes of $1.1 \pm 0.09 \times 10^{5} \mu \mathrm{m}^{3}$ and $1.7 \pm 0.1 \times 10^{5} \mu \mathrm{m}^{3}$, respectively. When adjusted for cell size, the bioluminescence capacity per unit surface area of cultured cells was similar to that of freshly col-
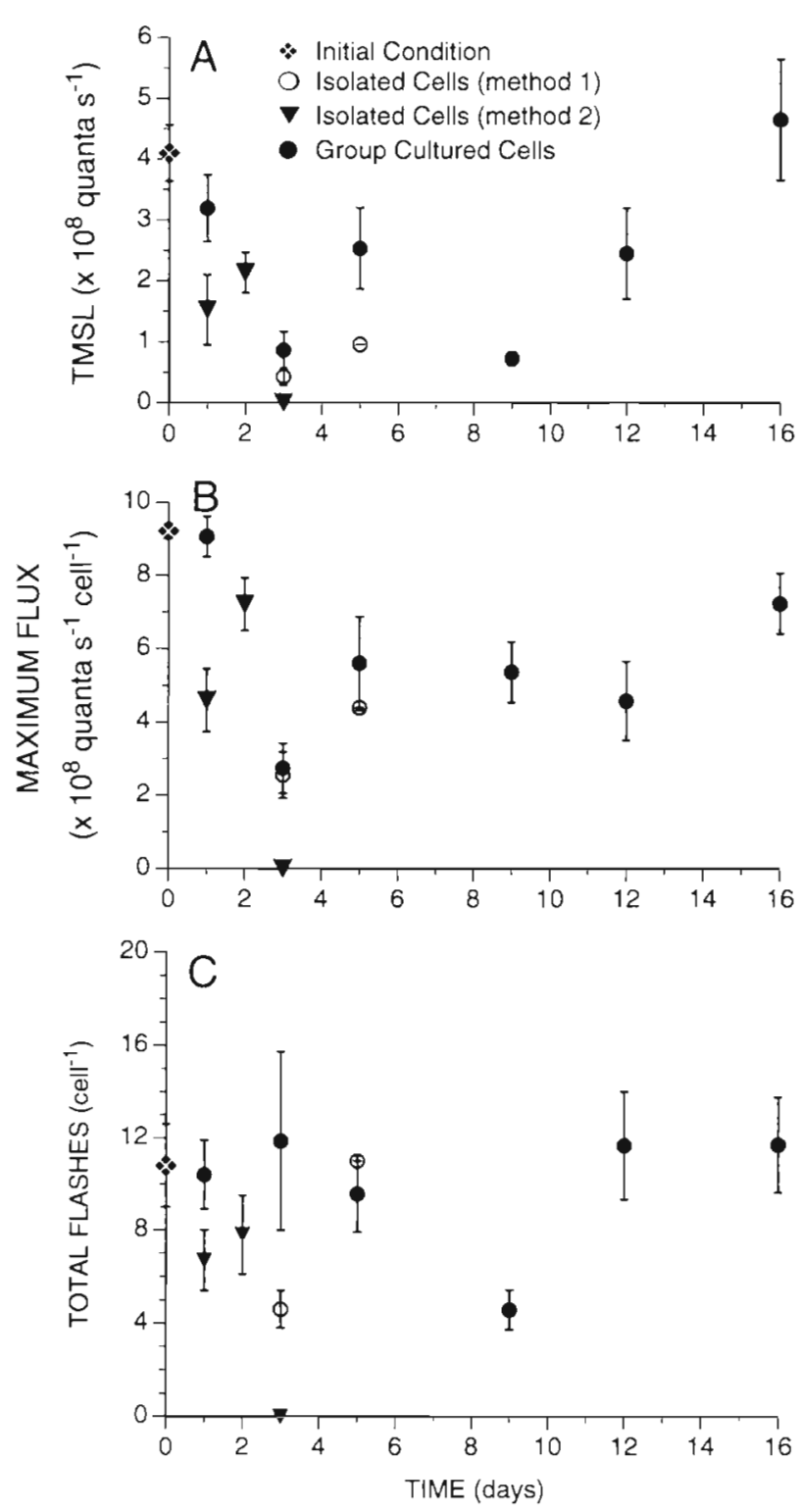

Fig. 3. Bioluminescence of Protoperidinium cf divergens after incubation without added prey (Expts 3 and 4; see Materials and methods: experimental design'). (A) Total mechanically stimulable bioluminescence per cell. TMSL decreased during the first few days of starvation, and then increased to initial values. (B) Maximum flux per cell. (C) Total number of flashes per cell was unaffected by group starvation (ANOVA, $p>$ 0.05 ), although single starved cells exhibited a decrease in flash number Values represent means $\pm \mathrm{SE}$

lected cells (1-way ANOVA, $p>0.05$ ), and there was no significant difference in either maximum quantum flux cell-1 or total number of flashes cell-1. (Table 4) (Fisher's PLSD, $p>0.05$ ).

The bioluminescence of Protoperidinium cf. divergens incubated on Gymnodinium sanguineum for $4 \mathrm{~d}$ was compared to that of cells maintained on a G. san- 
Table 4. Total stimulated bioluminescence of Protoperidinium cf. divergens and P. crassipes. Cultured cells were maintained on a Gonyaulax polyedra diet. Total mechanically stimulable luminescence (TMSL) was elicited by maintained stirring until depletion of light emission. Surface area (SA) calculated from mean equivalent cell diameter (see 'Materials and methods: analysis') Values represent means $\pm 1 \mathrm{SE}$. n: number of cells measured

\begin{tabular}{|c|c|c|c|c|c|c|}
\hline & $\begin{array}{c}\text { TMSL } \\
\text { (quanta cell } \\
\text { (q) }\end{array}$ & $\begin{array}{l}\text { Cell length } \\
(\mu \mathrm{m})\end{array}$ & $\begin{array}{l}\text { Cell width } \\
(\mu \mathrm{m})\end{array}$ & $\begin{array}{c}\text { TMSL SA-1 } \\
\text { (quanta cell }{ }^{-1} \mathrm{~mm}^{-2} \text { ) }\end{array}$ & $\begin{array}{l}\text { Total no. of } \\
\text { flashes cell }\end{array}$ & $n$ \\
\hline \multicolumn{7}{|l|}{ P. cf divergens } \\
\hline Cultured & $6.2 \pm 0.9 \times 10^{8}$ & $75 \pm 1$ & $56 \pm 2$ & $9.6 \pm 1.0 \times 10^{10}$ & $9.7 \pm 1.6$ & 19 \\
\hline Freshly collected & $15.9 \pm 2.7 \times 10^{8}$ & $81 \pm 2$ & $68 \pm 2$ & $10.5 \pm 1.8 \times 10^{10}$ & $12.5 \pm 2.5$ & 11 \\
\hline \multicolumn{7}{|l|}{ P. crassipes } \\
\hline Cultured & $7.9 \pm 1.6 \times 10^{8}$ & $79 \pm 1$ & $78 \pm 0.4$ & $6.0 \pm 1.3 \times 10^{10}$ & $5.8 \pm 0.8$ & 12 \\
\hline
\end{tabular}

Table 5. Paired comparison between first and second mechanically stimulated flashes of Protoperidinium cf. divergens and $P$. crassipes cells cultured on a Gonyaulax polyedra diet. Flashes were elicited by maintained stirring. Values represent means \pm 1 SE. n: number of cells tested. 'Significant difference within species between values for first and second flashes (paired $t$-test. $\mathrm{p}<0.05$ )

\begin{tabular}{|c|c|c|c|c|c|c|c|c|}
\hline Flash & $\begin{array}{l}\text { Maximum } \\
\text { flux } \\
\text { (quanta s }{ }^{-1} \text { ) }\end{array}$ & $\begin{array}{l}\text { Rise time } \\
\text { (ms) }\end{array}$ & $\begin{array}{c}\text { Decay rate } \\
\left(\% \mathrm{~s}^{-1}\right)\end{array}$ & $\begin{array}{l}\text { Total decay } \\
\text { time (ms) }\end{array}$ & $\begin{array}{l}\text { Total } \\
\text { duration } \\
\text { (ms) }\end{array}$ & $\begin{array}{c}\text { Quantum } \\
\text { emission } \\
\text { (quanta flash }{ }^{-1} \text { ) }\end{array}$ & $\begin{array}{l}\text { \% TMSL } \\
\text { flash }^{-1}\end{array}$ & $\mathrm{n}$ \\
\hline \multicolumn{9}{|c|}{ Protoperidinium cf. divergens } \\
\hline First & $8.9 \pm 0.5 \times 10^{6}$ & $45 \pm 4$ & $2.6 \pm 0.1$ & $104 \pm 5$ & $151 \pm 7$ & $5.1 \pm 0.3 \times 10^{7}$ & $15.8 \pm 2.4$ & 17 \\
\hline Second & $8.4 \pm 0.7 \times 10^{8}$ & $35 \pm 4$ & $2.3 \pm 0.3$ & $144 \pm 24$ & $189 \pm 28$ & $5.9 \pm 1.0 \times 10^{7}$ & $16.6 \pm 3.5$ & 17 \\
\hline \multicolumn{9}{|c|}{ Protoperidinium crassipes } \\
\hline First & $4.7 \pm 0.2 \times 10^{9}$ & $24 \pm 1$ & $2.9 \pm 0.2$ & $71 \pm 4$ & $96 \pm 5$ & $1.9 \pm 1.4 \times 10^{8}$ & $34 \pm 5$ & 16 \\
\hline Second & $3.8 \pm 0.3 \times 10^{9}$ & $24 \pm 1$ & $3.1 \pm 0.2$ & $76 \pm 9$ & $100 \pm 9$ & $1.4 \pm 1.7 \times 10^{8}$ & $24 \pm 3$ & 16 \\
\hline
\end{tabular}

guineum diet for $1.8 \mathrm{mo}$. There was no significant difference in TMSL, total number of flashes cell ${ }^{-1}$, or cell size (ANOVA, $p>0.05$ ), and only a barely significant change in maximum flux (ANOVA, $p=0.05$ ). Therefore diet during the preincubation period did not affect bioluminescence measured after a $4 \mathrm{~d}$ incubation, and there was no apparent degradation of the physiological state of $P$. cf. divergens cultures maintained on a $G$. sanguineum diet for more than $50 \mathrm{~d}$. The lack of change in bioluminescence with long-term maintenance on a non-luminescent diet suggests that the luminescent chemistry is synthesized de novo and is not obtained through the diet.

\section{Size-dependent interspecific differences in bioluminescence}

Even though the TMSL of the larger species Protoperidinium crassipes was greater than that of $P$. cf. divergens, when expressed per unit surface area, total bioluminescence per cell was less than that of $P$. cf. divergens (Table 4). Individual flashes were brighter than those of $P$. cf. divergens but had. shorter rise and decay times (Table 5). Neither species displayed dramatic differences between first and second flashes. $P$. crassipes flashes averaged $100 \mathrm{~ms}$ in duration with a rise time of 24 ms while those of $P$. cf. divergens were approximately 150 to $190 \mathrm{~ms}$ in duration with rise times of 35 to $45 \mathrm{~ms}$.

\section{Swimming speed during maintenance without added prey}

The speed of actively swimming Protoperidinium cf. divergens cells (53 to $64 \mu \mathrm{m}$ diameter) maintained in group conditions without added prey was measured every 2 to $3 \mathrm{~d}$. Even though the swimming speed of these cells significantly decreased from an initial value of $0.98 \pm 0.02 \mathrm{~mm} \mathrm{~s}^{-1}$ to $0.83 \pm 0.02 \mathrm{~mm} \mathrm{~s}^{-1}$ after $12 \mathrm{~d}$ (Fisher's PLSD, $p<0.05$ ), this represented a decrease of only $1 \% \mathrm{~d}^{-1}$. Cells presumably maintained nutrition and swimming ability through cannibalism, because a greater decrease in swimming speed would be expected if no food supply were available. In fact, cells maintained individually without added prey were dead in 3 to $5 \mathrm{~d}$. 


\section{DISCUSSION}

The hypotheses tested in the present study, except for $\mathrm{H}_{0} 4$, were rejected. Therefore prey species does affect the bioluminescence of Protoperidinium $\left(\mathrm{H}_{0} 1\right)$, bioluminescence is not necessarily related to population growth rate $\left(\mathrm{H}_{0} 2\right)$, prey concentration does affect bioluminescence $\left(\mathrm{H}_{0} 3\right)$, and cannibalism increases bioluminescence to high levels even when no added prey are present $\left(\mathrm{H}_{0} 4\right)$.

\section{Effect of red tide dinoflagellate diet}

The results of the present study show that the bioluminescence of Protoperidinium cf. divergens is significantly affected by the species and cell abundance of
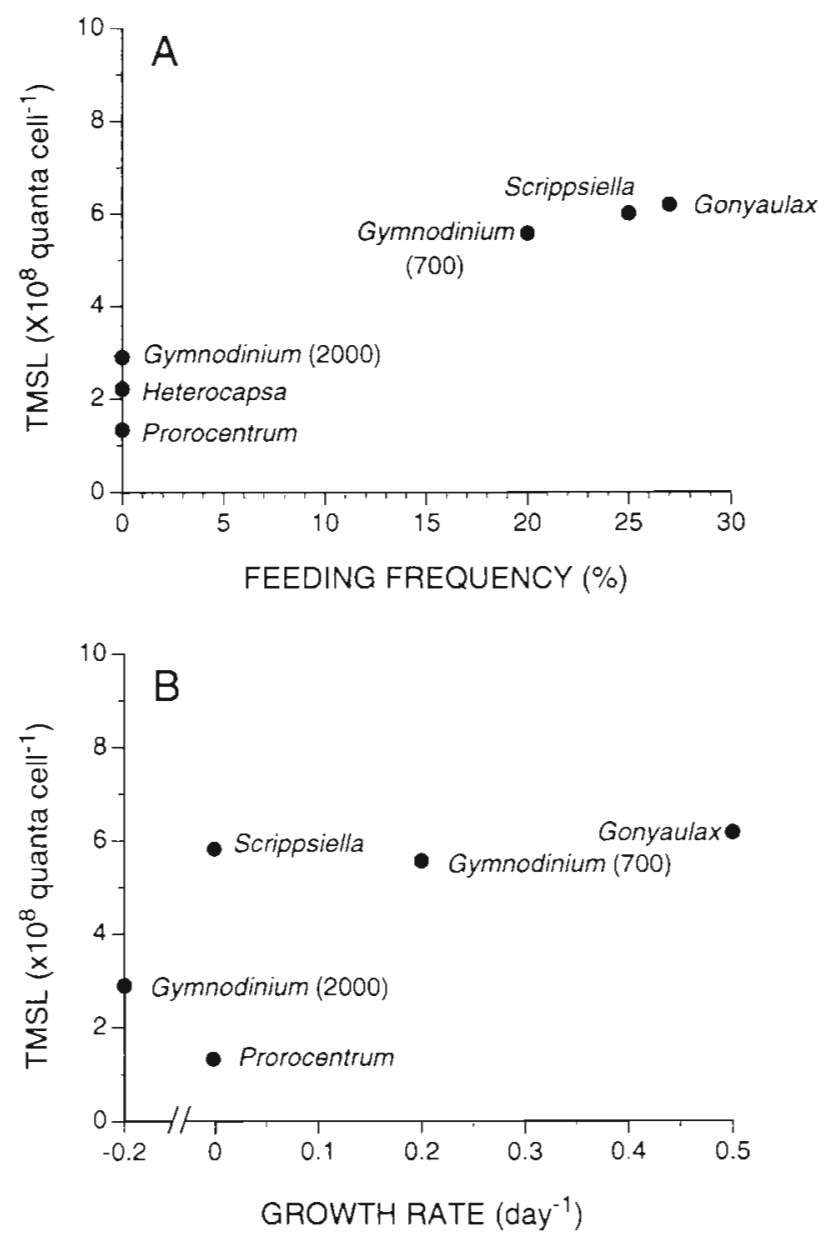

Fig. 4. Relationship between feeding, growth, and bioluminescence of Protoperidinium cf. divergens for various autotrophic and mixotrophic dinoflagellate diets (see Table 1. Expt 1). (A) TMSL as a function of instantaneous feeding frequency. (B) TMSL as a function of population growth rate Feeding and population growth data from Jeong \& Latz (1994) red tide dinoflagellate diets. For all diets the TMSL of $P$. cf. divergens fed on dinoflagellate prey was not significantly correlated with population growth, but instead with feeding frequency, the percent ratio of $P$. cf. divergens cells with a pallium (containing a prey cell) to total cells at any one time (Fig. 4). Bioluminescence may be an indicator of in situ feeding frequency even when no population growth occurs.

Previously, high levels of bioluminescence in Protoperidinium huberi feeding on mixed and unialgal diatom diets have been shown to be associated with high population growth rates (Buskey et al. 1994). For P. cf. divergens, only its optimal dinoflagellate diet of Gonyaulax polyedra supported the relationship between high bioluminescence and population growth rate (Fig. 5).

Based on the results of the present study, the following relationships between bioluminescence and in situ abundance of Protoperidinium of. divergens are expected: during Gonyaulax polyedra red tides, high population growth rates and high bioluminescence of P. cf. divergens would occur. During Prorocentrum cf.
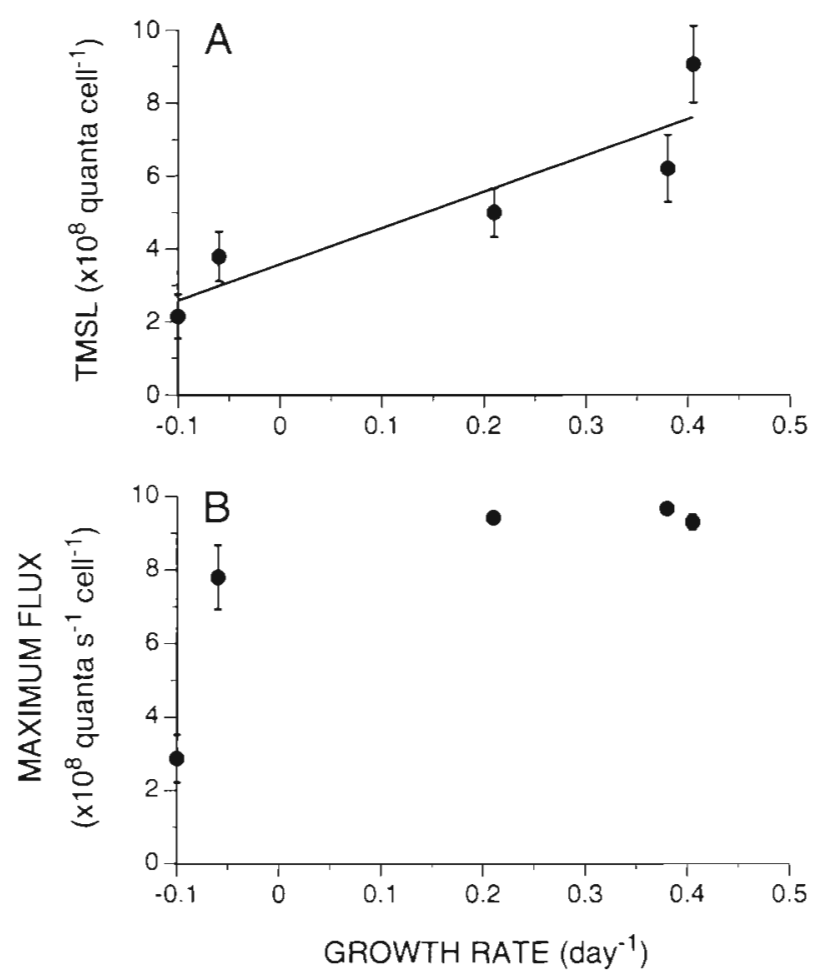

Fig. 5. Bioluminescence of Protoperidinium cf. divergens as a function of population growth rate for a Gonyaulax polyedra diet. (A) TMSL. The equation of the linear regression was TMSL $=3.58 \times 10^{8}+\left(9.95 \times 10^{8}\right) \times($ growth rate $) ; \mathrm{R}^{2}=0.83$. (B) Maximum flux per cell. Calculated from the data displayed in Fig. 2 using the growth rate data of Jeong \& Latz (1994). Values represent means $\pm 1 \mathrm{SE}$ 
balticum red tides, low bioluminescence and abundance of $P$. cf. divergens are predicted because no feeding on this prey occurs. During Gymnodinium sanguineum red tides, low bioluminescence and abundance are predicted at high prey concentrations $\geq 2000$ cells $\mathrm{ml}^{-1}$, while at low prey concentrations $\leq 700$ cells $\mathrm{ml}^{-1}$ high bioluminescence and abundance of Protoperidinium cf. divergens would occur. During Scrippsiella trochoidea red tides, high bioluminescence is predicted due to high feeding rates, even though the abundance of $P$. cf. divergens would be low.

\section{Effect of cannibalism}

There was a dramatic difference between the bioluminescence of Protoperidinium cf. divergens maintained individually without added prey, in which cells became nonluminescent prior to death and/or after $3 \mathrm{~d}$, and group maintained cells which resisted starvation through cannibalism. Cannibalism, which appeared to be most important after $3 \mathrm{~d}$ without added prey, resulted in increased survival time and gradually increasing levels of bioluminescence, which eventually reached levels similar to those of cells maintained under optimal prey conditions. Therefore, if feeding occurs, whether due to cannibalism or ingestion of red tide dinoflagellate prey, $P$. cf divergens cells can produce bright bioluminescence, even when population growth does not occur. Cannibalism might be an important strategy for maintaining high bioluminescence after red tides when $P$. cf. divergens abundance is high and red tide dinoflagellate prey abundance is low

\section{Bioluminescence dynamics}

TMSL per unit size of freshly collected Protoperidinium cf. divergens cells, as well as that of cultured cells maintained on an optimum Gonyaulax polyedra diet, followed the correlation of Seliger et al. (unpubl., cited in Buskey et al. 1992). This correlation states that, for autotrophic dinoflagellates, TMSL scales to approximately $10^{11}$ quanta cell ${ }^{-1} \mathrm{~mm}^{-2}$ surface area. Therefore cultured cells of $P$. cf. divergens were healthy and expressed maximum bioluminescence capacity.

There were few significant differences between the emission properties of first and second flashes of Protoperidinium cf. divergens and P. crassipes cells maintained on a Gonyaulax polyedra diet. This indicates that there is a single mechanism for synchronization and light production in the Iuminescent microsources within the cell (Widder \& Case 1982). Flash kinetics were similar to those measured for Protoperidinium spp. in the north Atlantic $\left(60^{\circ} \mathrm{N}, 20^{\circ} \mathrm{W}\right)$ during May 1991, when rise times averaged $29 \mathrm{~ms}$, flash duration was $141 \mathrm{~s}$, maximum flux was $1.1 \times 10^{10}$ quanta $s^{-1}$, and each cell produced approximately 6 flashes with a TMSL of $2 \times 10^{9}$ quanta cell ${ }^{-1}$ (Latz unpubl data). The rapid kinetics of Protoperidinium spp. flashes are similar to those of other dinoflagellates such as $G$. polyedra and Noctiluca scintillans (Eckert 1965, Latz unpubl data), but are faster than those of Pyrocystis species (Widder \& Case 1981, Jess 1985).

Changes in bioluminescence capacity were reflected in the number of quanta resulting from each flash, not the total number of flashes produced by a cell. This suggests that the bioluminescence excitation process, which involves an action potential propagated along the vacuole membrane (Eckert 1965, Widder \& Case 1981) leading to proton flux across the membrane of the vesicles containing the luminescent chemistry (Hastings \& Dunlap 1986), is independent of quantum emission. A reduction in flash quantum flux, presumably due to reduced amount of energy available for the luminescent system, may reduce the effectiveness of bioluminescence as an antipredation behavior (Esaias \& Curl 1972, White 1979)

\section{Energy utilization}

Based on the results of the present study, the energy requirements for swimming, bioluminescence, and growth can be considered. Two lines of evidence are important: (1) differences in the population growth rate of Protoperidinium feeding on different dinoflagellate prey did not necessarily signify differences in bioluminescence $\left(\mathrm{H}_{0} 2\right)$, and (2) there was no significant difference in swimming speed even when there was a difference in bioluminescence. These data suggest that energy requirements for bioluminescence are less than those for reproduction. When nutritional status is high, sufficient energy is available for all metabolic needs, including bioluminescence and growth. For medium levels, insufficient energy is available for growth, although bioluminescence may still be high. When the nutritional status is low, available energy is inadequate to support bioluminescence and growth. Therefore energy utilization by Protoperidinium cf. divergens may be prioritized in the following order swimming (for grazing) > bioluminescence (to reduce predation) $>$ reproduction (for population increase).

Bioluminescence may be a sensitive indicator of the nutritional status and feeding history of natural populations of Protoperidinium, especially when suboptimal prey conditions result in low population growth rates. 
Acknowledgements. We are grateful to M. D. Ohman for use of his particle counter, to N. Shiva and C. Severn for technical assistance, and to P. J. S. Franks and M. D. Ohman for comments on the manuscript. Supported by the Office of $\mathrm{V}_{\text {iival }}$ Research (grant N00014-92-J-1475 to M.I.L.).

\section{LITERATURE CITED}

Abrahams MV, Townsend LD (1993) Bioluminescence in dinoflagellates: a test of the burglar alarm hypothesis. Ecology 258:258-260

Beers JR, Reid FMH, Stewart GL (1982) Seasonal abundance of the microplankton population in the North Pacific Central Gyre. Deep Sea Res 29:227-245

Biggley WH, Swift E, Buchanan RJ, Seliger HH (1969) Stimulable and spontaneous bioluminescence in the marine dinoflagellates, Pyrodinium bahamensis, Gonyaulax polyedra, and Pyrocystis lunula. J Gen Physiol 54:96-122

Buskey EJ, Coulter CJ, Brown SL (1994) Feeding, growth and bioluminescence of the heterotrophic dinoflagellate Protoperidinium huberi. Mar Biol 121:373-380

Buskey EJ, Strom S, Coulter C (1992) Bioluminescence of heterotrophic dinoflagellates from Texas coastal waters. J Exp Mar Biol Ecol 159:37-49

Eckert R (1965) Bioelectric control of bioluminescence in the dinoflagellate Noctiluca. Science 147:1140-1145

Esaias WE, Curl HC Jr (1972) Effect of dinoflagellate bioluminescence on copepod ingestion rates. Limnol Oceanogr 17:901-906

Gifford DJ, Dagg MJ (1991) The microzooplankton-mesoplankton link: consumption of planktonic protozoa by the calanoid copepods Acartia tonsa and Neocalanus plumchrus Murukawa. Mar Microb Food Webs 5:161-177

Guillard RRL, Ryther JH (1962) Studies of marine planktonic diatoms. I. Cyclotella nana Hustedt, and Detonula confervacea (Cleve) Gran. Can J Microbiol 8:229-239

Hallegraeff GM, Reid DD (1986) Phytoplankton species successions and their hydrological environment at a coastal station off Sydney. Aust J Mar Freshwat Res 37:361-377

Hastings $J W$. Dunlap JC (1986) Cell-free components in dinoflagellate bioluminescence. The particulate activity scintillons; the soluble components: luciferase, luciferin and luceferin-binding protein. Methods Enzymol 133 $307-327$

Jacobson DM (1987) The ecology and feeding biology of thecate heterotrophic dinoflagellates. PhD thesis, Woods Hole Oceanographic Institution/Massachusetts Institute of Technology Joint Program

Jacobson DM. Anderson DM (1986) Thecate heterotrophic dinoflagellates: feeding behavior and mechanisms. J Phycol 22:249-258

Jeong HJ (1994a) Predation effects of the calanoid copepod Acartia tonsa on a population of the heterotrophic dinoflagellate Protoperidinium cf. divergens in the presence of co-occurring red-tide dinoflagellate prey. Mar Ecol Prog Ser 111:87-97

Jeong HJ (1994b) Predation by the heterotrophic dinoflagellate Protoperidinium cf. divergens on copepod eggs and early naupliar stages. Mar Ecol Prog Ser 114:203-208

Jeong HJ (1995) The interactions between microzooplank-

This article was presented by D. A. Caron (Senior Editorial Advisor), Woods Hole, Massachusetts, USA tonic grazers and dinoflagellates causing red tides in the open coastal waters off southern California. PhD thesis, University of California, San Diego

Jeong HJ, Latz MI (1994) Growth and grazing rates of the heterotrophic dinoflagellates Protoperidinium spp. on red tide dinoflagellates. Mar Ecol Prog Ser 106:173-185

Jess MM (1985) The comparative effect of temperature on mechanically stimulated flash responses of three bioluminescent dinoflagellates, Pyrocystis fusiformis, Pyrocystis noctiluca, and Noctiluca miliaris. MA thesis, University of California, Santa Barbara

Kamykowski D, Reed RE, Kirkpatrick GJ (1992) Comparıson of sinking velocity, swimming velocity, rotation and puth characteristics among six marine dinoflagellate species. Mar Biol 111:319-328

Lapota D, Geiger ML, Stiffey AV, Rosenberger DE, Young DK (1989) Correlations of planktonic bioluminescence with other oceanographic parameters from a Norwegian fjord. Mar Ecol Prog Ser 55:217-227

Lapota D, Rosenberger DE, Lieberman SH (1992a) Planktonic bioluminescence in the pack ice and the marginal ice zone of the Beaufort Sea. Mar Biol 112:665-675

Lapota D. Young DK, Bernstein SA, Geiger ML, Huddell HD, Case JF (1992b) Diel bioluminescence in heterotrophic and photosynthetic marine dinoflagellates in an Arctic fjord. J Mar Biol Ass UK 72:733-744

Latz MI, Lee AO (1995) Spontaneous and stimulated bioluminescence of the dinoflagellate Ceratocorys horrida (Peridiniales). J Phycol 31:120-132

Lessard EJ (1984) Oceanic heterotrophic dinoflagellates: distribution, abundance and role as microzooplankton. PhD thesis, University of Rhode lsland, Kingston

Lessard EJ, Rivkın RB (1986) Nutrition of microzooplankton and macrozooplankton from McMurdo Sound. Antarct $J$ US 21:187-188

Mensinger AF, Case JF (1992) Dinoflagellate luminescence increases susceptibility of zooplankton to teleost predation. Mar Biol 112:207-210

Nicolas MT, Morse D, Bassot JM, Hastings JW (1991) Colocalization of luciferin binding protein and luciferase to the scintillons of Gonyaulax polyedra revealed by immunolabeling after fast-freeze fixation. Protoplasma 160:159-1.66

Sweeney BM (1971) Laboratory studies of a green Noctiluca from New Guinea. J Phycol 7:53-58

Swift E, Sullivan JM, Batchelder HP, Van Keuren J, Vaillancourt RD. Bidigare RR (1995) Bioluminescent organisms and bioluminescence measurements in the North Atlantic Ocean near latitude $59.5^{\circ} \mathrm{N}$, longitude $21^{\circ} \mathrm{W}$. J (ieophys Res 100:6527-6547

White HH (1979) Effects of dinoflagellate bioluminescence on the ingestion rates of herbivorous zooplankton. J Exp Mar Biol Ecol 36:217-224

Widder EA. Case JF (1981) Bioluminescence excitation in a dinoflagellate. In: Nealson $\mathrm{KH}$ (ed) Bioluminescence current perspectives. Burgess Publishing Co, Minneapolis p $125-132$

Widder EA, Case JF (1982) Luminescent microsource activity in bioluminescence of the dinoflagellate, Pyrocystis fusiformis. J Comp Physiol 145:517-527

Winer BJ (1971) Statistical principles in experimental design McGraw-Hill, New York

Manuscript first received: November 21, 1994

Revised version accepted: August 29, 1995 